\title{
Morphogenic and structural characteristics and chemical composition of grass aruana, submitted to nitrogen fertilization
}

\section{Características morfogênicas, estruturais e composição química de capim-aruana, submetido à adubação nitrogenada}

\author{
Alice Mariana Hupp Sacramento ${ }^{1 *}$; Olga Cedro de Menezes²; Tarcísio Marques \\ Barros $^{3}$; Diego Novais Pinheiro 3 ; Soraya Maria Palma Luz Jaeger ${ }^{4}$; Ossival Lolato \\ Ribeiro $^{4}$; Carlos Eduardo Crispim de Oliveira Ramos ${ }^{4}$; Gêisa Araújo de Oliveira ${ }^{1}$
}

\begin{abstract}
This study aimed at evaluating the morphogenic and structural characteristics of Panicum maximum Jacq. cv. Aruana, as well as its chemical composition after submitting it to different nitrogen levels. The experiment was performed by adopting a randomized block design which included four treatments $\left(0,75,150\right.$ and $225 \mathrm{~kg} \mathrm{ha}^{-1}$ of $\left.\mathrm{N}\right)$ and three replications, in $100 \mathrm{~m}^{2}$ plots. Twice a week, for the 63 days of regrowth, the morphogenic characteristics were determined and estimated, after which the chemical composition was assessed. The aruana grass revealed a quadratic and positive response to the nitrogen fertilization, and showed a remarkable rise in the elongation rates, leaf appearance and senescence, besides the number of live leaves per tiller and final leaf length. However, the nitrogen fertilization reduced the phyllochron and leaf life in the aruana grass, implying the direct effect of nitrogen on the flow of tissues. A quadratic and positive effect of the nitrogen fertilization was observed for the dry mass production, from $5,840.80 \mathrm{~kg} \mathrm{ha}^{-1}$ for plants lacking the nitrogen fertilization to $8,862.55 \mathrm{~kg} \mathrm{ha}^{-1}$ for those fertilized with $225 \mathrm{~kg} \mathrm{ha}^{-1}$ of $\mathrm{N}$. Thus, while the nitrogen fertilization positively affected both tillering and morphogenesis, the $\mathrm{N}$ doses used in this study were insufficient to induce any change in the chemical composition of the aruana grass.
\end{abstract}

Key words: Panicum maximum. Pasture. Tropical grass. Urea.

\section{Resumo}

\begin{abstract}
Objetivou-se avaliar as características morfogênicas, estruturais e a composição química do Panicum maximum Jacq. cv. Aruana sob diferentes doses de nitrogênio. O experimento foi instalado em delineamento de blocos casualizados com quatro tratamentos $\left(0,75,150\right.$ e $225 \mathrm{~kg} \mathrm{ha}^{-1}$ de N) e três repetições, em parcelas de $100 \mathrm{~m}^{2}$. As características morfogênicas foram determinadas duas vezes por semana, durante 63 dias de rebrotação, após a qual estimou-se e determinou-se a composição química. Plantas de capim-aruana responderam de maneira quadrática e positiva à adubação nitrogenada com aumento significativo nas taxas de alongamento, aparecimento e senescência de folhas bem como no
\end{abstract}

1 Mestres em Ciência Animal, Universidade Federal do Recôncavo da Bahia, UFRB, Cruz das Almas, BA, Brasil. E-mail: alicehuppzootecnia@gmail.com; tamarquesgbi@gmail.com; geisaaraoli@gmail.com

2 Discente, Curso de Mestrado em Ciência Animal, UFRB, Cruz das Almas, BA, Brasil. E-mail: olgacedro@hotmail.com

3 Discente, Curso de Doutorado em Zootecnia, Universidade Federal da Bahia, UFBA, Salvador, BA, Brasil. E-mail: diegonovais@ zootecnista.com.br

4 Profs. Drs., Departamento de Zootecnia, UFRB, Cruz das Almas, BA, Brasil. E-mail: sorayajaeger@ufrb.edu.br; ossival@ufrb. edu.br; carlosramos@ufrb.edu.br

* Author for correspondence 
número de folhas vivas por perfilhos e no comprimento final da lâmina. Por outro lado, a adubação nitrogenada diminui o filocrono e a duração de vida das folhas em capim-aruana, o que indica efeito direto do nitrogênio no fluxo de tecidos. Observou-se efeito quadrático e positivo da adubação nitrogenada para a produção de massa seca, que variaram de $5.840,80 \mathrm{~kg} \mathrm{ha}^{-1}$ para plantas sem adubação nitrogenada a $8.862,55 \mathrm{~kg} \mathrm{ha}^{-1}$ para a adubação de $225 \mathrm{~kg} \mathrm{ha}^{-1} \mathrm{de} \mathrm{N}$. A adubação nitrogenada influencia o perfilhamento e a morfogênese, porém, as doses utilizadas de $\mathrm{N}$ não foram suficientes para afetar a composição química em plantas de capim-aruana.

Palavras-chave: Gramínea tropical. Panicum maximum. Pastagem. Ureia.

\section{Introduction}

Grazing management ensures the maximum usage of the forage produced and its conversion for animal products, by maintaining the perennial pasture, through facilitating the continuous emission of leaves and tillers post grazing, thus restoring the leaf area of the plant. To accomplish this, the dynamics of the growth and development of the plants constituting the pasture must be ascertained (CASAGRANDE et al., 2010).

Therefore, the evaluation of grasses makes it possible to know better the ecophysiological interactions of the plant, allowing a coherent and sustainable management for each fodder species. One of the methods for evaluating grasses is morphogenesis, which can be defined as the dynamics of growth and development of the plant's shape in space, and can be expressed in terms of appearance, expansion of new organs and their senescence (LEMAIRE, 1997).

Carbon and nitrogen $(\mathrm{N})$ are the crucial elements essential for the growth and development dynamics of the plant organs. Thus, forage production can be maximized by increasing the addition of fertilizers, $\mathrm{N}$ in particular, through a significant increase in the tissues flow (CABRAL et al., 2012).

With proper management and correct fertilization, pastures can persist and even increase their yield, thus continuing to be sustainable for several years. It is noteworthy, that virtually all the knowledge available until the present time, comes from institutions sited in the southeastern and southern regions of the country, which in practice greatly limits their usefulness as a guiding tool in pasture management under other edaphoclimatic conditions, such as the Southern Recôncavo of Bahia.

Panicum maximum cv. Aruana, a forage species, was introduced into the market in 1989 by the Animal Science Institute of the Department of Agriculture and Supply of the State of São Paulo. As it is short and has a reduced stem length, this grass has been recommended for sheep.

Similar to a majority of the tropical species, further scientific data is required on the morphophysiological characteristics of aruana grass, and the response to nitrogen fertilization. The goal of this study was to estimate the way in which different doses of nitrogen affect the morphogenetic, structural and chemical composition of the aruana grass, under the conditions prevailing in the Recôncavo region of Bahia.

\section{Material and Methods}

The experiments were performed at the Federal University of Recôncavo da Bahia (Universidade Federal do Recôncavo da Bahia), in the municipality of Cruz das Almas - Bahia, at the geographic coordinates of S $12^{\circ} 40^{\prime} 12^{\prime \prime}$ latitude and W $39^{\circ} 06^{\prime}$ 07" longitude, on average, at 220 maltitude.

Based on the Köppen classification, the climate of the region is type $A w$ and $A m$, tropical hot and humid. The experienced mean annual precipitation is $1,224 \mathrm{~mm}$, with an annual average temperature of $24.5^{\circ} \mathrm{C}$ and relative humidity of about $80 \%$ (ALMEIDA, 1999). The climatic data during the experimental period (from December 2016 to July 
2017) were collected at the EMBRAPA Mandioca and Fruticultura meteorological station, 4 km away from the experimental area (Table 1).
In 2016, the experimental area was planted with the Panicum maximum cv. Aruana in the cohesive alic yellow latosolclass, clayey in texture and of flat relief (RIBEIRO et al., 1998).

Table 1. Mean values of maximum temperature (Tmax), minimum temperature (Tmin), mean temperature (Tmed) and precipitation between Dec. 2016 and July 2017.

\begin{tabular}{ccccc}
\hline Month & $\operatorname{Tmax}\left({ }^{\circ} \mathrm{C}\right)$ & $\operatorname{Tmin}\left({ }^{\circ} \mathrm{C}\right)$ & Tmed $\left({ }^{\circ} \mathrm{C}\right)$ & Precipitation $(\mathrm{mm})$ \\
\hline December-2016 & 31.7 & 22.3 & 27.0 & 60.0 \\
January-2017 & 32.0 & 21.7 & 26.85 & 14.5 \\
March-2017 & 31.5 & 22.4 & 26.95 & 43.9 \\
April-2017 & 29.5 & 22.2 & 25.85 & 152.6 \\
May-2017 & 27.4 & 20.9 & 24.15 & 171.2 \\
June-2017 & 26.8 & 20.0 & 23.40 & 135.9 \\
July-2017 & 25.7 & 19.7 & 22.70 & 143.0 \\
\hline
\end{tabular}

Data weather station of EMBRAPA.

In the experimental area, the soil showed the following chemical characteristics in the $0-20 \mathrm{~cm}$ layer: $\mathrm{pH}$ in $\mathrm{H}_{2} \mathrm{O}$ : 4.5; $\mathrm{P}\left(\right.$ Mehlich $\left.^{-1}\right)$ : $10.08 \mathrm{mg}$ $\mathrm{dm}^{-3} ; \mathrm{K}\left(\right.$ Mehlich $\left.^{-1}\right): 0.80$ cmolc dm $^{-3} ; \mathrm{Ca}^{+2}(\mathrm{KCl}$

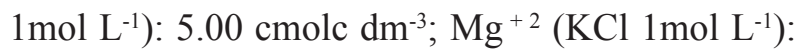
$4.00 \mathrm{cmolc} \mathrm{dm}^{-3}$ and $\mathrm{Al}^{+3}\left(\mathrm{KCl} 1 \mathrm{~mol} \mathrm{~L}^{-1}\right): 0.84$ cmolcdm ${ }^{-3} ; \mathrm{H}+\mathrm{Al}$ (calcium acetate $0.5 \mathrm{~mol} \mathrm{~L}^{-1}$ ): $4.00 \mathrm{cmolc} \mathrm{dm}^{-3}$; base saturation $28.00 \%$, organic matter (Boyocus Method): $13.04 \mathrm{~g} \mathrm{dm}^{-3}$, CTC

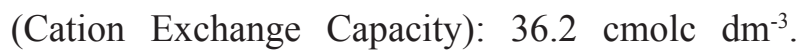
Using the results from the soil analysis, the $\mathrm{pH}$ was corrected using dolomitic limestone (12.6 tons ha ${ }^{-1}$ ) to raise the saturation by bases to $60 \%$. After a 60 day reaction period of using commercial limestone reaction with $92 \%$ PRNT, basic soil fertilization was performed, using a combination of urea $16 \mathrm{~kg}$, single superphosphate $20 \mathrm{~kg}$ and potassium chloride 20 $\mathrm{kg}$. Fertilization and liming corrections were done based on the method of Cantarutti et al. (1999).

Four treatments were performed, in which the following nitrogen doses were used: $0,75,150$ and 225 $\mathrm{kg} \mathrm{ha}^{-1}$. The randomized complete block experimental design was adopted, with three replications, to give a total of 12 experimental units. A pasture area of 1,520 $\mathrm{m}^{2}$ (40 $\mathrm{m}$ long by $38 \mathrm{~m}$ wide) was delimited for the experiment, and divided into three blocks of $400 \mathrm{~m}^{2}$ each, with $2.0 \mathrm{~m}$ spacing between them. Each plot was $100 \mathrm{~m}^{2}(10.0 \times 10.0 \mathrm{~m})$ in size.

During the rainy season, just after the cut of uniformity, nitrogen fertilization was done using urea. The experimental period was started on 04/05/2017 after the cut of standardization and extended until $05 / 07 / 2017$, for 63 days in total.

Twice a week, the morphogenic and structural characteristics were estimated in 12 representative tillers per experimental unit, selected randomly based on the technique of Carrere et al. (1997). The clumps that were sampled were marked off with banners while the tassels sampled were secured with colored thread. Leaf blade lengths and number of live leaves per tiller were measured.

Leaf blade length was measured using a ruler graduated in centimeters. The length was measured from the ligula to the end of each leaf blade. Stem length was measured from the soil level to the ligula of the last expanded leaflet. Leaf senescence was measured from the time tissue necrosis commenced until at least $50 \%$ of the leaf became necrotic (VAN SOEST, 1994). 
With this information, the morphogenic and structural variables were evaluated based on the methodology of Chapman and Lemaire (1993). The morphogenic variables are as follows:

- Leaf appearance rate (LAR): number of emerged leaves per tiller divided by the number of days of the evaluation period - leaves/tiller/ day;

- Phyllochron (Phil): inverse of the leaf appearance rate - days/ leaf/tiller;

- Leaf elongation rate (LER): sum of all the elongations of the leaf blades per tiller divided by the number of days of the evaluation period - cm/tiller/day;

- Leaf life duration (LLD): length of time fromthetimethe leaf appears until it dies. Estimation is done using the following equation proposed by Lemaire and Chapman (1996): LLD = NLL x Phyllochron (days);

The structural variables evaluated included:

- Final length of the leaf blade (FLLB): average length of all the leaves present in the tiller, measured from leaf apex to ligule $(\mathrm{cm})$;

- Number of live leaves per tiller (NLT): mean number of leaves in elongation and elongated per tiller, ignoring the senescent leaves in each tiller;

- Number of senescent leaves (NSL): mean number of senescent leaves in each tiller;

- Number of expanded leaves (NEL): mean number of elongated leaves in each tiller;

- Number of leaves in expansion (NLEx): average number of leaves in elongation in each tiller;

- Stem height (SH): length of the ligule of the last expanded leaf related to the insertion in the source tiller $(\mathrm{cm})$;
To determine the population density of the tillers and evaluate the productive traits of the aruana grass, a square $0.25 \mathrm{~m}^{2}$ structure was used for the forage harvest of each experimental unit. The forage was cut at $10 \mathrm{~cm}$ height above the soil level, packed in plastic bags and immediately transported to the UFRB bromatology laboratory; there, the number of tillers was counted and the components were separated, as listed: green leaf blades, green shoots (stem + leaf sheath) and dead material (dead leaves). After the separation was completed, all the components were oven dried at $55^{\circ} \mathrm{C}$ for $72 \mathrm{~h}$, based on the INCTCA G-001/1 technique, in line with the method of Detmann et al. (2012). The weight was again noted to obtain the dry mass in the air; next, it was ground in a Willey mill (1 $\mathrm{mm}$ sieve), packed in pots, sealed tight and labeled with the respective treatments and repetitions, and sent for chemical analysis. Then, neutral detergent (DM), insoluble fiber (NDF), acid detergent insoluble fiber (ADF), lignin (LIG), total nitrogen $(\mathrm{N})$, and protein content $(\mathrm{CP})$ were obtained by multiplying the $\mathrm{N}$ content by factor 6.25 .

From the data obtained, the assumptions of normality of errors and homogeneity of variance were tested employing the Shapiro-Wilk and Bartlett tests, respectively. The data were submitted to the analysis of variance and regression analysis. The models were selected based on the significance $(5 \%)$ of the linear and quadratic coefficients and the coefficient of determination. The regression equations were adjusted depending upon the means of the treatments, with $\mathrm{r}^{2}$ being obtained by the quotient between the sum of the squares of the regression and the total sum of the squares. The tool used for the statistical analysis was the computer program R (version 2.12.0).

\section{Results and Discussion}

Nitrogen fertilization was found to have no effect on $(\mathrm{P}>0.05)$ the number of expanded leaves (NEL) and number of leaves in expansion (NLEx), giving average values of 5.15 and 1.60 leaves tiller-1, respectively. 
Nitrogen fertilization affected the leaf appearance rate $(\mathrm{LAR})$ of the aruana grass $(\mathrm{P}=0.0002)$, with a quadratic and positive adjustment, estimated at 0.04 and 0.13 leaves of tiller ${ }^{-1}$ day $^{-1}$, for the 0 and $225 \mathrm{~kg}$ ha $^{-1}$ doses of $\mathrm{N}$, respectively (Figure 1 ).

Figure 1. Leaf appearance rate (LAR) of aruana grass in response to nitrogen doses.

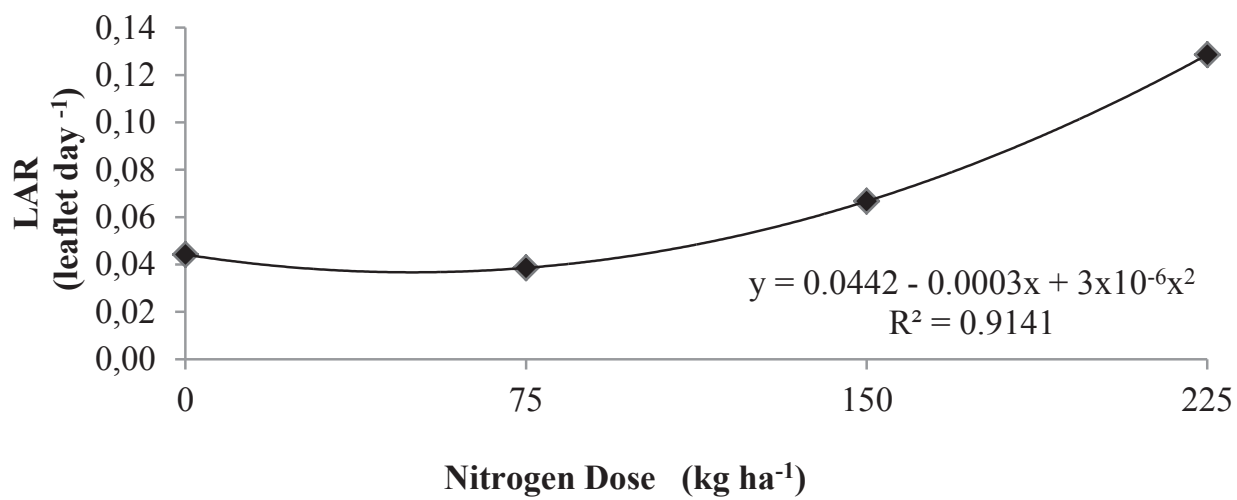

LAR can be considered the morphogenic feature that deserves greater prominence, since it directly influences the final size of the leaf, the population density of tiller and the number of leaves of the tiller-1 (NABINGER; CARVALHO, 2009; DIFANTE et al., 2011). LAR and NLEx generally present a negative correlation, evidencing that the faster the leaf appearance, the shorter the time available for its complete expansion (LEMAIRE et al., 2011).
The phyllochron, which is the inverse of LAR, was influenced $(\mathrm{P}=0.0121)$ by nitrogen fertilization with the data adjusted to the negative linear model (Figure 2).

The phyllochron values varied from 30.41 days for plants without nitrogen fertilization to 16.71 days for plants fertilized with $225 \mathrm{~kg} \mathrm{ha}^{-1}$ of N. For each $\mathrm{kg} \mathrm{ha}^{-1}$ of $\mathrm{N}$ added, the phyllochron decreased by 0.061 days.

Figure 2. Phyllochron (Phil) of aruana grass in response to nitrogen doses.

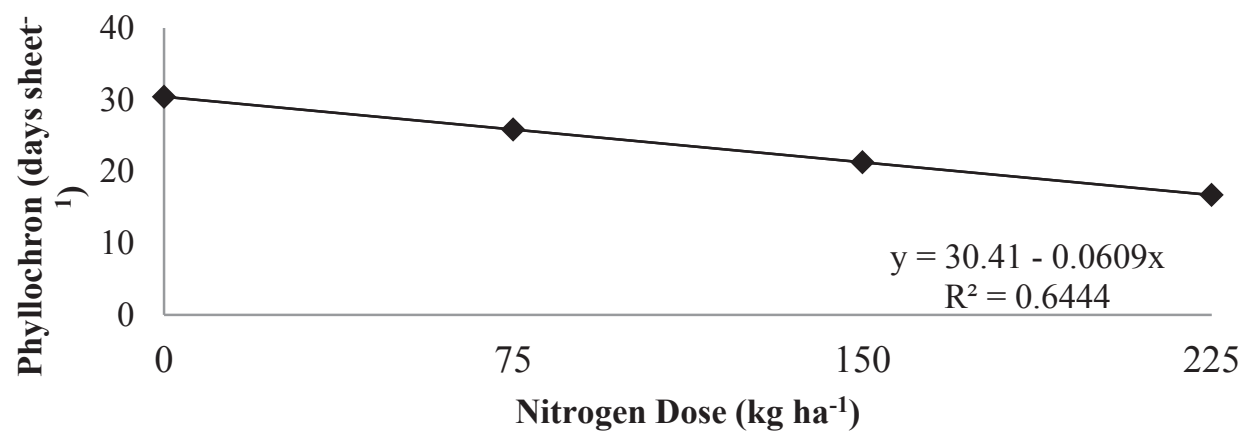

Phyllochron is the interval between the sequential emergence of two consecutive leaves on the main stem. From the results, it is evident that the nitrogen reduces the time required for leaf expansion to occur. In this context, Pompeu et al. (2010) verified, in the plants of the aruana grass, that both the nitrogen fertilization and defoliation regime affected the phyllochron, which declined at 
the higher dosages. These authors confirm that the shortened phyllochron, post nitrogen fertilization, is due to the combination of leaf elongation in proportion to sheath elongation, under conditions of sufficient temperature and nutrient availability.

In fact, this study showed that the leaf elongation rate (LER) was affected $(\mathrm{P}=0.0002)$ by nitrogen fertilization, with the data adjusted to the positive quadratic model (Figure 3). The $30.5 \mathrm{~kg} \mathrm{ha}^{-1}$ dose of $\mathrm{N}$ induced the lowest LER in the aruana grass, to $1.24 \mathrm{~cm}$ tiller $^{-1}$ day $^{-1}$. The highest fertilization dose of $225 \mathrm{~kg} \mathrm{ha}^{-1}$, induced an estimated LER value of $5.02 \mathrm{~cm}$ tiller $^{-1}$ day $^{-1}$.

Figure 3. Leaf elongation rate (LER) of aruana grass in response to nitrogen doses.

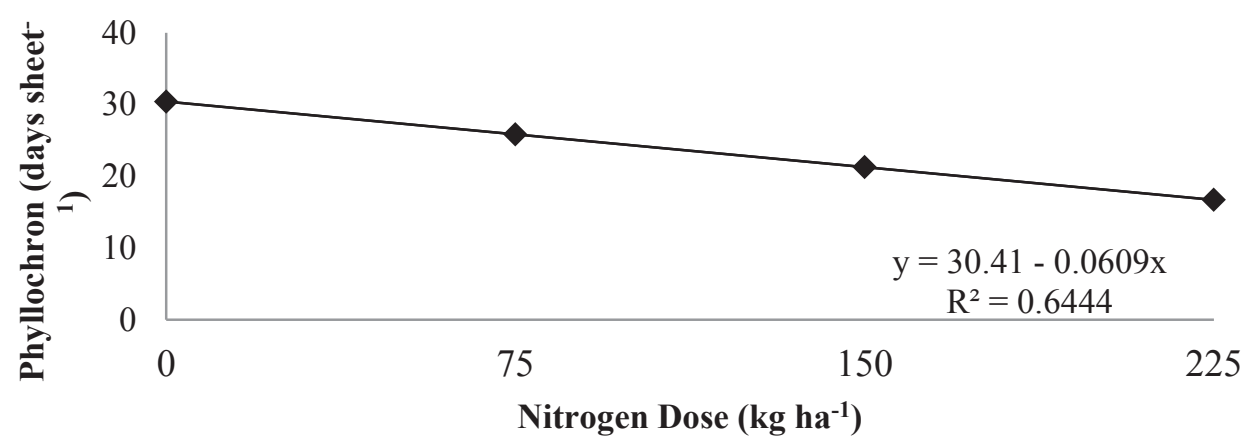

Indeed, the higher doses of nitrogen fertilization raised the nitrogen availability in the soil, which most likely induced an increase in its uptake by the plant. In the apical meristem, nitrogen was observed to increase the number of dividing cells and stimulate cell stretching (SCHNYDER et al., 2000). This enabled a notable escalation in flow tissues of fodder plants, including increased rates of appearance (Figure 1) and leaf elongation (Figure 3 ), as well as a shorter phyllochron (Figure 2).

In their study, Pompeu et al. (2010) employing four nitrogen doses $\left(0,125,250\right.$ and $375 \mathrm{mg} \mathrm{dm}^{-3}$ of $\mathrm{N}$ ) also reported positive effects caused by the nitrogen fertilization on the leaf elongation rate, estimated at 1.51 and $2.56 \mathrm{~cm}_{\text {tiller }}^{-1}$ day $^{-1}$ for the 0 and $375 \mathrm{mg} \mathrm{dm}^{-3}$ of $\mathrm{N}$, respectively. From these results, it is clear that the leaf production in the aruana grass shows a positive response to the nitrogen fertilization, showing variations only in the magnitude of the process.

The final leaf length (FLLB) of the aruana grass was positively influenced $(\mathrm{P}=0.0008)$ by the quadratic nitrogen doses (Figure 4).

Figure 4. Final length of the leaf blade (FLLB) of aruana grass in response to nitrogen doses.

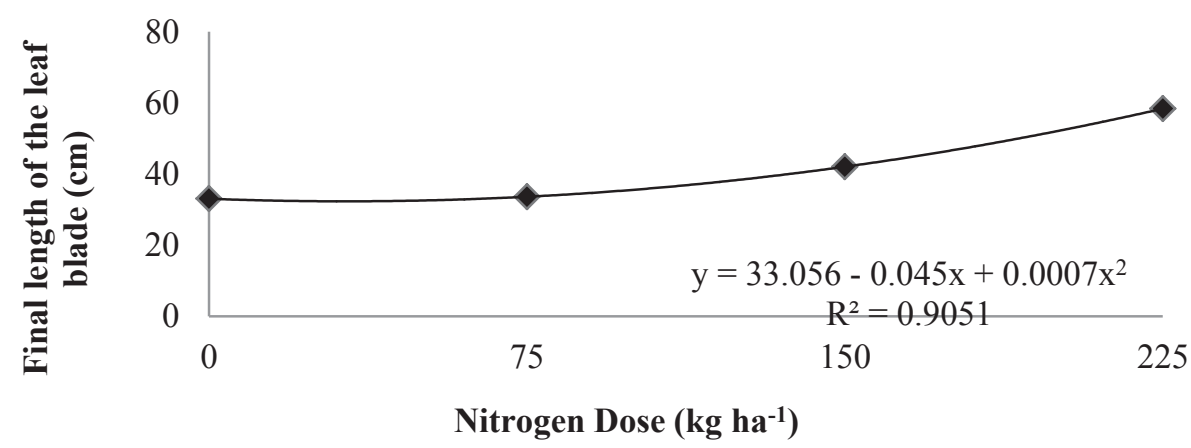


Lemaire and Chapman (1996) reported that the influence exerted by $\mathrm{N}$ on the FLLB is due to the correlation between the FLLB and LER. The present study too noted this fact, where the highest LER value was obtained after the highest $\mathrm{N}$ dose $(225 \mathrm{~kg})$ was applied. This higher LER contributes to the higher FLLB, proving the effect of $\mathrm{N}$ as a promoter of the cell division process, stimulating the yield of new cells.
The nitrogen doses $(\mathrm{P}=0.0365)$ affected the leaf life duration (LLD) of the aruana grass in a quadratic manner, according to the equation (Figure 5). The adjusted model revealed that the nitrogen fertilizer applied decreased the 132.7 day $\left(0 \mathrm{~kg} \mathrm{ha}^{-1}\right.$ dose) leaf life span to 83.7 days (225 $\mathrm{kg} \mathrm{ha}^{-1}$ dose).

Figure 5. Leaf life duration (LLD) of aruana grass in response to nitrogen doses.

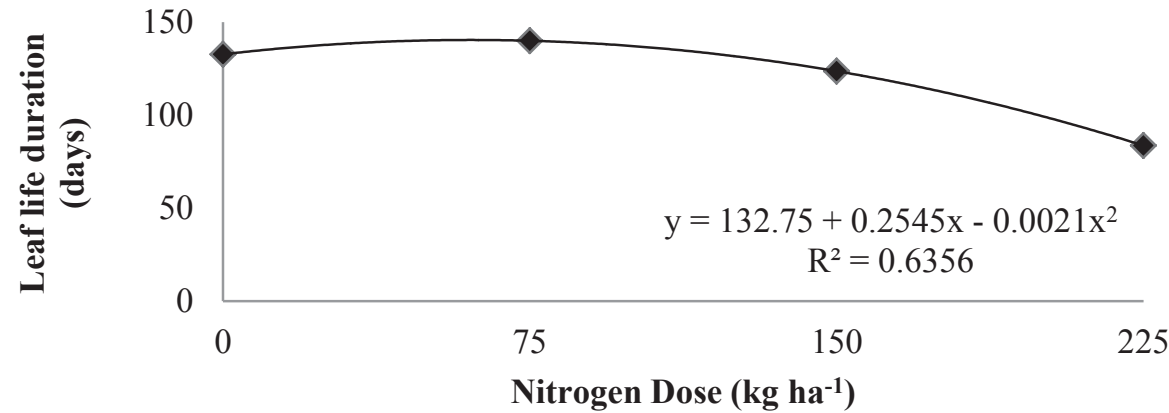

This decreased leaf life span is a a greater photosynthetic capacity than do the older morphophysiological response of the plant to leaves.

the increased rates of appearance (Figure 1) and leaf elongation (Figure 3). The response patterns revealed by leaf appearance, leaf elongation, phyllochron, and leaf life rates suggest a high rate of tissue renewal induced by the nitrogen application, which can cause positive effects on the production system, because the leaves of younger plants possess

The number of live leaves per tiller (NLT) of the aruana grass was affected $(\mathrm{P}=0.0104)$ by the nitrogen doses in a quadratic fashion (Figure 6). The NLT was noted to be in the range of 5.64 to 7.43 leaves per tiller ${ }^{-1}$, for the absence of fertilization and application of $225 \mathrm{~kg} \mathrm{ha}^{-1}$ of $\mathrm{N}$, respectively.

Figure 6. The number of live leaves (NLT) per tiller of aruana grass in response to nitrogen doses.

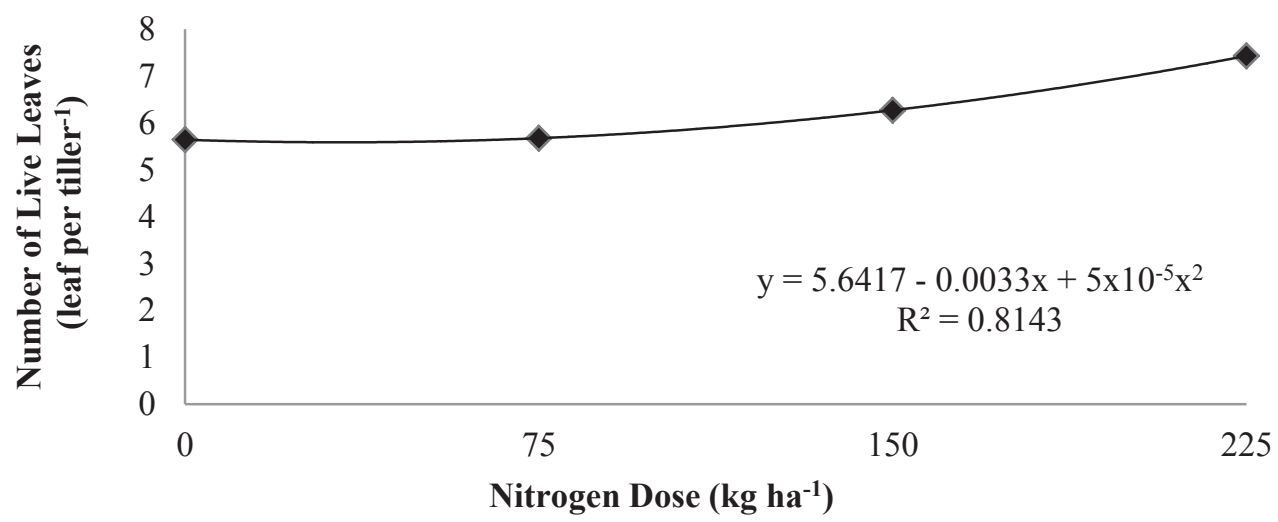


Pompeu et al. (2010) reported NLT of 2.33 and 3.08 leaves of tiller ${ }^{-1}$ in response to 0 to $375 \mathrm{mg}$ $\mathrm{dm}^{-3}$ of $\mathrm{N}$, respectively, values that are below those observed in the present study.

Lemaire and Chapman (1996) found that the LAR correlates with the NLTby tiller, where the highest NLT in response to the increase in the N doses is because during a high uptake of $\mathrm{N}$, there is also an increase in the LAR.

The increasing nitrogen dosesexerted a quadratic effect $(P=0.0015)$ on the number of senescent leaves (NSL) in the aruana grass, estimated at 1.21 and 4.03 leaves tiller ${ }^{-1}$ at the levels of 0 and $225 \mathrm{~kg}$ $\mathrm{ha}^{-1}$ of $\mathrm{N}$, respectively (Figure 7).

Figure 7. Number of senescent leaves (NSL) per tiller of aruana grass in response to nitrogen doses.

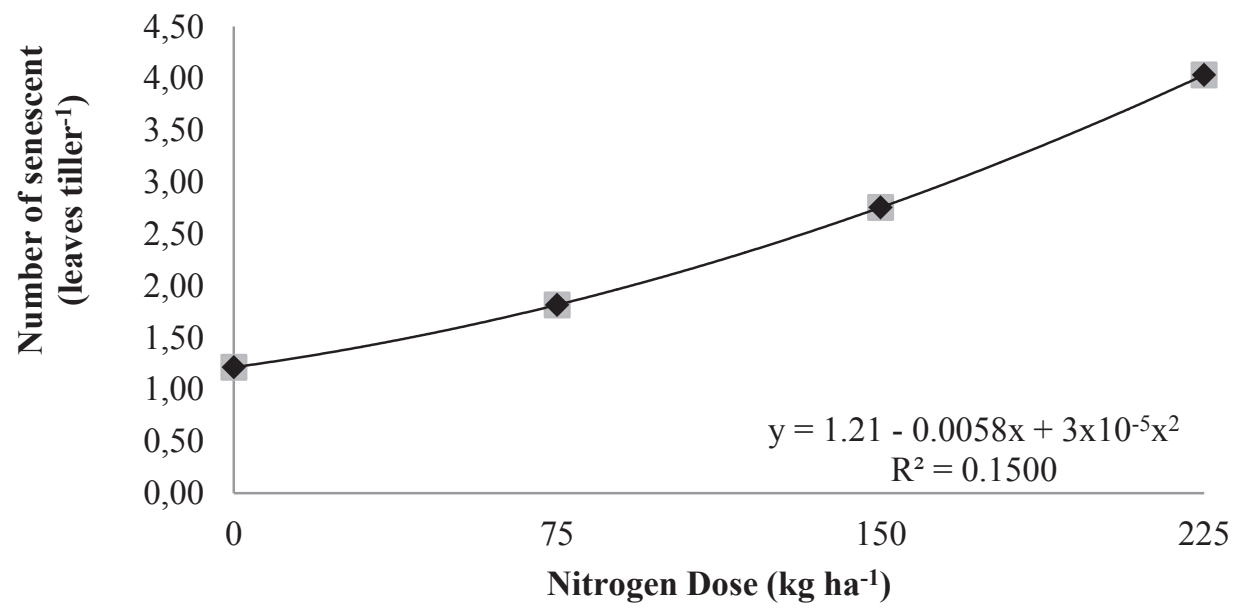

The growth rhythm of the plant in response to the increasing nitrogen doses, in terms of high rates of appearance (Figure 1) and leaf elongation (Figure 3), supports the senescence of the first formed leaves because the competition for the photo assimilates rises (GOMIDE et al., 2003). NSL is one of the most critical factors in the analysis of forage mass accumulation for animal production because it determines the net forage mass accumulated by area (IWAMOTO et al., 2015).

Stem height $(\mathrm{SH})$ in the aruana grass showed a linear increase $(P=0.0016)$ in response to the nitrogen dose (Figure 8). When no fertilizer is added, stem height of $29.9 \mathrm{~cm}$ is noted; for every 1 $\mathrm{kg} \mathrm{ha}^{-1}$ of $\mathrm{N}$ added, a further rise of $0.12 \mathrm{~cm}$ of stem height is expected.

Figure 8. Stem height (SH) of aruana grass in response to nitrogen doses.

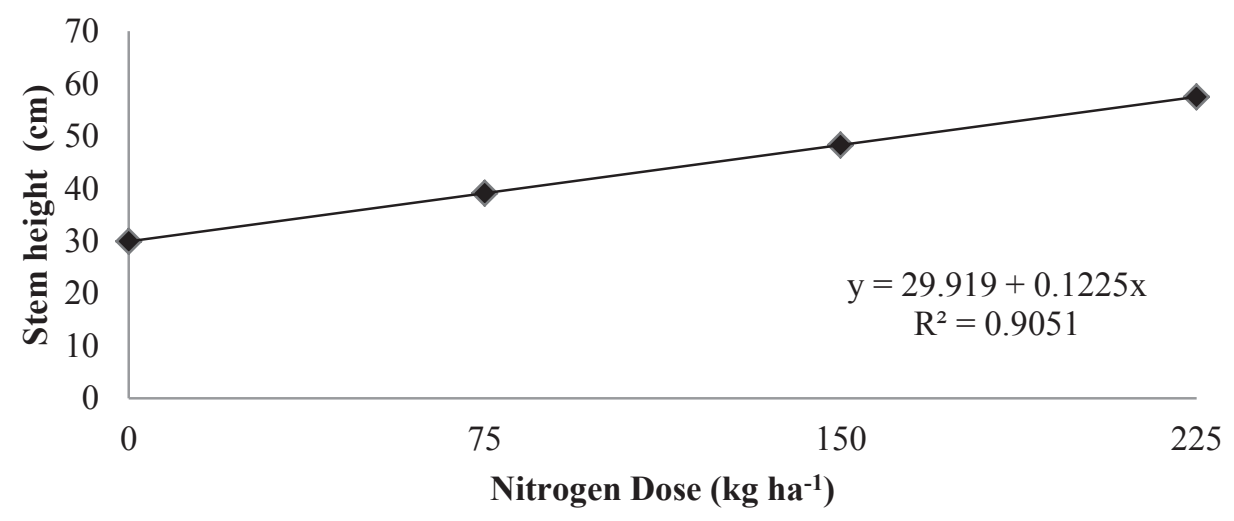


As mentioned earlier, the nitrogen that the plant absorbed induces cell division and expansion in the apical meristems (SCHNYDER et al., 2000). During cell differentiation, the meristematic region divides into two and the cells of the upper part differentiated into the leaf blade, while those of the lower part formed the leaf sheath. Thus, genetically, the greater appearance (Figure 1) and leaf elongation (Figure 3) were associated with taller stem height. The stem is a vital plant organ necessary to maintain the forage plant, with the ability to increase in length and diameter over time, in order to support the leaf weight (SBRISSIA; SILVA, 2001). Besides this genetic programming, stem height may be enhanced by the intra-specific light competition (SILVA; NASCIMENTO JUNIOR, 2007).

Tiller population density (TPD) was positively affected $(\mathrm{P}=0.0068)$ with the quadratic nitrogen doses (Figure 9). The nitrogen uptake boosted the tiller population density, according to the adjusted equation, with the minimum point of $11 \mathrm{~kg} \mathrm{ha}^{-1}$, after which the values of this structural characteristic increased.

Figure 9. Tiller population density (TPD) of aruana grass in response to different nitrogen rates.

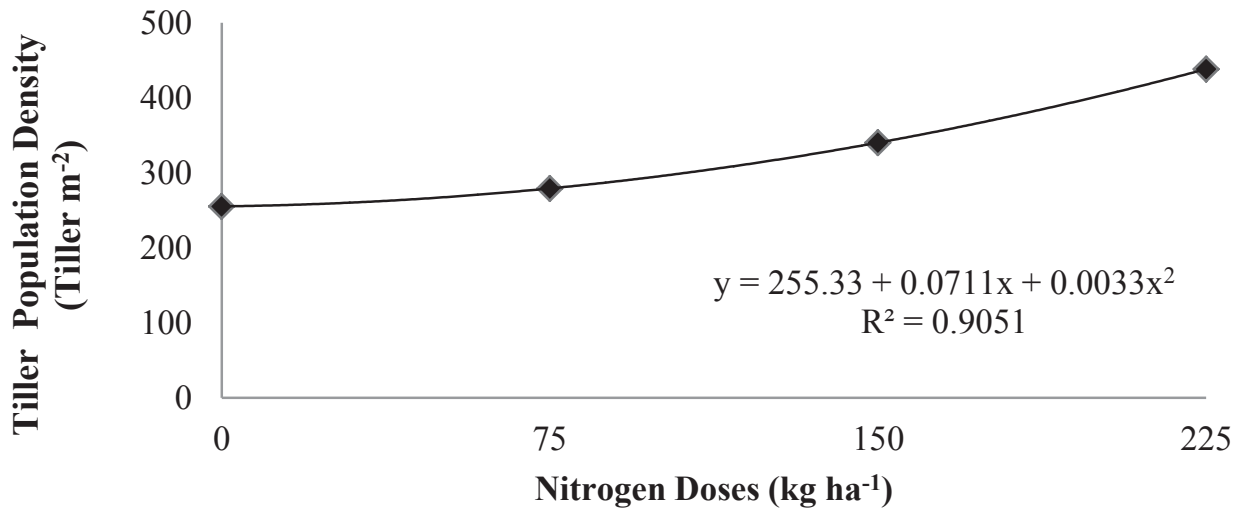

The tiller population density is a crucial structural feature that is very useful in pasture management, as it is linked to the perennial pasture (LEMAIRE; CHAPMAN, 1996). This trait arises from the balance between the tiller appearance and its mortality, which iscontrolled by the number of axillary buds present on each plant (CRUZ; BOVAL, 2000), which can be activated or not. The grasses are constituted by basic units termed phytomers, which include the leaf and leaf sheath, ligula, node, internode and axillary bud, at different growth stages (VALENTINE; MATTHEW, 1999). Thus, each new sheet formed has the potential of producing a new tiller induced by the presence of a new axillary bud. In this study, nitrogen fertilization increased the appearance of leaves (Figure 1) and decreased phyllochron (Figure 2) of the aruana grass and, therefore, increased the number of axillary buds, which differed in new tillers.

The effect of the nitrogen fertilizer as well as the season, or evaluation periods, on the tiller population density can be the factors that determine the biomass production and yield per tiller (ALENCAR et al., 2010). Basso et al. (2010) stated that the favorable climatic factors together with the nitrogen fertilization induce greater nitrogen assimilation by the plant, which stimulates the tillering and, thereby increases the appearance of the leaves on the plant.

The relation leaf blade:stem+sheath $(\mathrm{L} / \mathrm{S})$ ratio of the aruana grass was positively influenced ( $\mathrm{P}$ $=0.0023)$ by the nitrogen dosage administered according to the equation in a quadratic manner (Figure 10). 
Figure 10. Relation leaf bland:stem + sheath $(\mathrm{L} / \mathrm{S})$ of aruana grass in response to nitrogen doses.

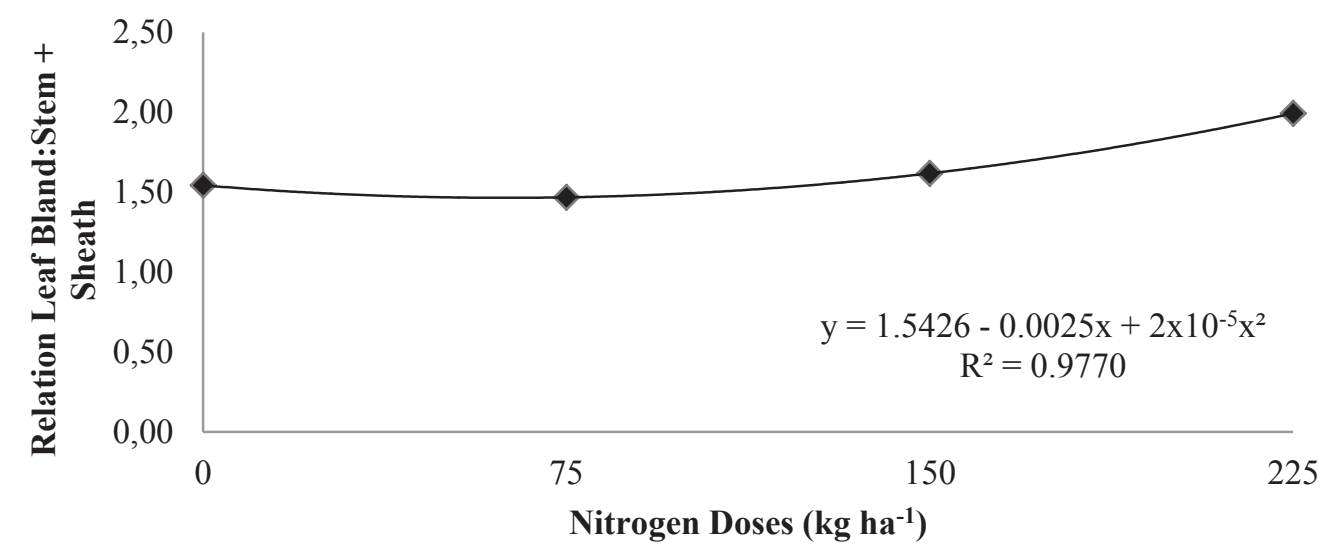

The L/S presented shows increasing values from the $6.25 \mathrm{~kg} \mathrm{ha}^{-1}$ nitrogen dose upwards, according to the adjusted model. The relation leaf blade:steam $(\mathrm{L} / \mathrm{S})$ is a very significant variable for animal nutrition, as well as fodder plant management, and can find use as an index of the nutritive value of the forage, this is because the greater the ratio, the better the forage quality the animal can consume. This is considered critical when the ratio is $1: 1$ as values below this would suggest a decline in the quantity and quality of fodder produced, which will be detrimental to the animal productivity (PINTO et al., 1994).

In this study, the reported values were greater than $1: 1$, indicating that aruana grass has a high leaf blade yield, and is therefore regarded as a high quality fodder species for animal production.

As far as dry mass production (DMP) is considered, the nitrogen fertilization exerted a quadratic and positive effect $(\mathrm{P}=0.0386)$, as shown in Figure 11.

Figure 11. Dry mass production (DMP) of aruana grass in response to nitrogen doses.

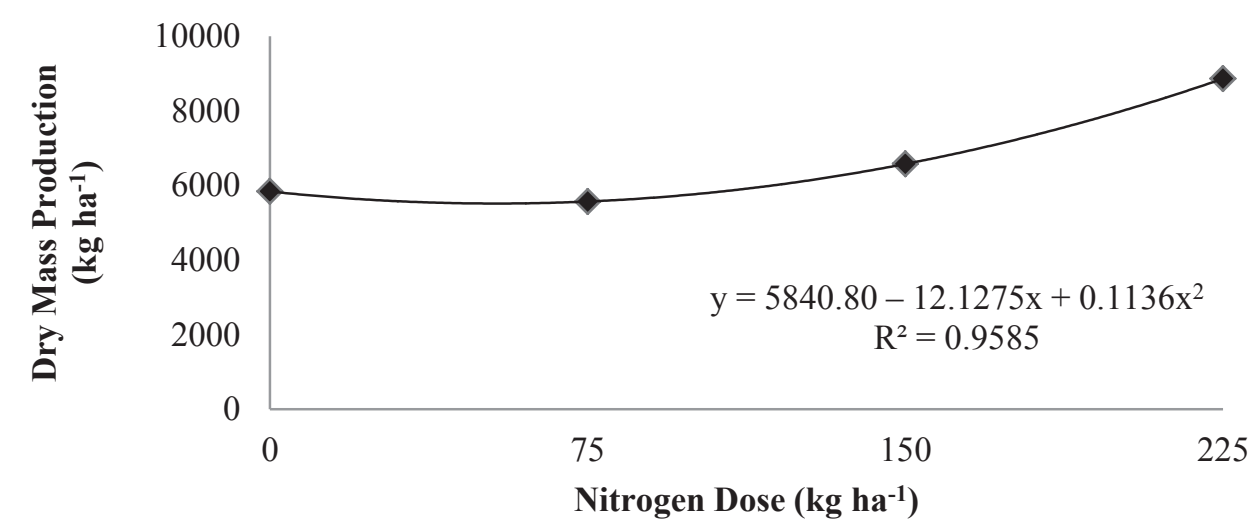

The escalation in the aruana grass yield in thebiomass through carbon fixation (BRAZ et al., in response to the increase in the $\mathrm{N}$ doses is 2011; MARTUSCELLO et al., 2015). Roma et al. possiblybecause the $\mathrm{N}$ behaves as a controlling (2012) gave evidence for the positive effect of the factor for the various growth and development $\mathrm{N}$ on the heightened yield of the dry matter, chiefly processes in these plants, resulting in the increase caused by the higher tillering. 
Table 2 reveals no significant effect $(\mathrm{P}>0.05)$ among the treatments for the chemical composition of the aruana grass.

Table 2. Chemical composition ( $\mathrm{gkg}^{-1}$ of DM) of Panicum maximum Jacq. cv. Aruana in response to the $\mathrm{N}$ dosages.

\begin{tabular}{ccccccc}
\hline \multirow{2}{*}{$\begin{array}{c}\text { Characteristics } \\
\text { evaluated }\end{array}$} & 0 & 75 & 150 & 225 & Media & CV\% \\
\cline { 2 - 4 } DM & 254.00 & 259.00 & 250.50 & 232.40 & 249.00 & 5.89 \\
MM & 134.10 & 126.20 & 123.50 & 114.60 & 124.60 & 5.45 \\
CP & 64.20 & 66.80 & 63.30 & 67.40 & 65.40 & 6.89 \\
NDF & 730.60 & 735.20 & 744.80 & 729.60 & 735.00 & 2.43 \\
ADF & 362.50 & 357.50 & 368.50 & 359.90 & 362.10 & 4.36 \\
HEM & 368.20 & 377.70 & 376.30 & 369.70 & 373.00 & 9.62 \\
LIG & 38.50 & 36.00 & 38.80 & 41.40 & 38.60 & 10.47 \\
\hline
\end{tabular}

$\mathrm{DM}=$ dry matter $\left(\mathrm{g} \cdot \mathrm{kg}^{-1}\right.$ of $\left.\mathrm{MN}\right) ; \mathrm{MM}=$ mineral matter; $\mathrm{CP}=$ crude protein; $\mathrm{NDF}=$ neutral detergent fiber; $\mathrm{ADF}=$ acid detergent fiber; $\mathrm{HEM}=$ hemicellulose; $\mathrm{LIG}=$ lignin; ${ }^{*} \mathrm{CV}=$ coefficient of variation.

Van Soest (1994) stated that the CP level in the aruana grass was most often below $70 \mathrm{~g} \mathrm{~kg}^{-1}$. This fails to meet the requirements of the nitrogen compounds for the proper functioning of the ruminal microbiota and, consequently, the use of potentially energetic substrates like fiber.

The NDF content was $735 \mathrm{~g} \mathrm{~kg}^{-1}$ DM. Mertens (1992) reported that the proportion of NDF is linked to the maximum dry matter consumption, whereas plants having high to generally higher levels (up to $500 \mathrm{gkg}^{-1}$ of DM) restrict the food intake and therefore the energy consumption. However, Van Soest (1994) demonstrated that values above 550 $\mathrm{gkg}^{-1}$ of NDF in the dry matter were negatively linked to feed intake. The ADF concentration observed was $362.10 \mathrm{gkg}^{-1} \mathrm{DM}$. These values, associated with the NDF appear to suggest the low consumption of the aruana grass, since according to Nussio et al. (1998) forages with ADF values close to or higher than $400 \mathrm{gkg}^{-1}$ of DM are consumed in low quantities. The results listed in Table 2 imply that the cut-off period employed in the 63-day study permitted increased fiber concentration.
In forage plants, the lignin level is the principal factor that restricts the plant cell walls from exposure to microbial digestion, thus hindering the digestion of this polymer in animals (VAN SOEST, 1994). However, the mean values resulting from the present study (Table 2) appear to be highly reasonable in the case of tropical grasses from the perspective of Van Soest (1994), as they fall below $40 \mathrm{~g} \mathrm{Kg}^{-1}$ and will not compromise their digestibility.

\section{Conclusions}

While the nitrogen fertilization factor is known to exert a quadratic effect on the morphogenic and structural traits of the aruana grass, facilitating higher dry matter yields, the $\mathrm{N}$ doses used in this study were inadequate to alter the chemical composition, which is related to forage quality.

\section{Acknowledgment}

The authors express their gratitude to CAPES for their support in the development of this work, and for the research grant bestowed. 


\section{References}

ALENCAR, C. A. B.; OLIVEIRA, R. A.; COSER, A. C.; MARTINS, C. E.; FIGUEIREDO, J. L. A.; CUNHA, F. F.; CECON, P. R.; LEAL, B. G. Produção de seis capins manejados por pastejo sob efeito de diferentes doses nitrogenadas e estações anuais. Revista Brasileira de Saúde e Produção Animal, Salvador, v. 11, n. 1, p. 48-58, 2010.

ALMEIDA, O. A. Informações metereológicas do CNP: mandioca e fruticultura tropical. Cruz das Almas: Embrapa-CNPMF, 1999. 35 p. (Documentos, 34).

BASSO, K. C.; CECATO, U.; LUGÃO, S. M. B.; GOMES, J. A. N.; BARBERO, L. M.; MOURÃO, G. B. Morfogênese e dinâmica do perfilhamento em pastos de Panicum maximum Jacq. cv. IPR-86 Milênio submetido a doses crescentes de nitrogênio. Revista Brasileira de Saúde e Produção Animal, Salvador, v. 11, n. 4, p. 976989, 2010.

BRAZ, T. G. S.; FONSECA, D. M.; FREITAS, F. P.; MARTUSCELLO, J. A.; SANTOS, M. E. R.; SANTOS, M. V.; PEREIRA, V. V. Morphogenesis of Tanzania guinea grass under nitrogen doses and plant densities. Revista Brasileira de Zootecnia, Viçosa, MG, v. 40, n. 7, p. 14201427, 2011. DOI: 10.1590/S1516-35982011000700004

CABRAL, W. B.; SOUZA, A. L.; ALEXANDRINO, E.; TORAL, F. L. B.; SANTOS, J. N.; CARVALHO, M. V. P. Características estruturais e agronômicas da Brachiariabrizantha cv. Xaraés submetida a doses de nitrogênio. Revista Brasileira de Zootecnia, Viçosa, MG, v. 41, n. 4, p. 846-855, 2012. DOI: 10.1590/S151635982012000400004

CANTARUTTI, R. B.; MARTINS, C. E.; CARVALHO, M. M. Pastagens. In: RIBEIRO, A. C.; GUIMARÃES, P. T. G.; ALVAREZ, V. H. Recomendações para $o$ uso de corretivos e fertilizantes em Minas Gerais. $5^{\mathrm{a}}$ Aproximação. Viçosa, MG: UFV, 1999. p. 332-341.

CARRERE, P.; LOUAULT, F.; SOUSSANA, J. F. Tissue turnover within grass-clover mixed swards grazed by sheep. Methodology for calculating growth, senescence and intake fluxes. Journal of Applied Ecology, Oxford, v. 34, n. 3, p. 333-348, 1997. DOI: $10.2307 / 2404880$

CASAGRANDE, D. R.; RUGGIERI, A. C.; JANUSCKIEWICZ, E. R.; GOMIDE, J. A.; REIS, R. A.; VALENTE, A. L. S. Características morfogênicas e estruturais do capim-marandu manejado sob pastejo intermitente com diferentes ofertas de forragem. Revista da Sociedade Brasileira de Zootecnia, Viçosa, MG, v. 39 , n. 10 , p. $2108-2115$, 2010. DOI: $10.1590 / \mathrm{S} 1516-$ 35982010001000002

CHAPMAN, D. F; LEMAIRE, G. Morphogenic and structural determinants of plant regrowth after defoliation. In: BAKER, M. J. (Ed.). Grasslands for our world. Wellington: SIR, 1993. p. 55-64.

CRUZ, P.; BOVAL, M. Effect of nitrogen on some morphogenetic traits of temperate and tropical perennial forage grasses. In: LEMAIRE, G.; HODGSON, J.; MORAES, A.; CARVALHO, P.C. de F.; NABINGER, C. (Ed.). Grassland ecophysiology and grazing ecology. New York: CABI Publishing, 2000. p. 151-168.

DETMANN, E.; SOUZA, M. A.; VALADARES FILHO, S. C.; QUEIROZ, A. C.; BERCHIELLI, T. T.; SALIBA, E. O. S.; CABRAL, L. S.; PINA, D. S.; LADEIRA, M. M.; AZEVEDO, J. A. G. Métodos para análise de alimentos - INCT - Ciência Animal. Visconde do Rio: Suprema, 2012. 214 p.

DIFANTE, G. S.; NASCIMENTO JÚNIOR, D.; SILVA, S. C.; EUClidES, V. P. B.; MONTAGNER, D. B. Características morfogênicas e estruturais do capimmarandu submetido a combinações de alturas e intervalos de corte. Revista Brasileira de Zootecnia, Viçosa, MG, v. 40, n. 5, p. 955-963, 2011. DOI: 10.1590/S151635982011000500003

GOMIDE, C. A. M.; GOMIDE, J. A.; ALEXANDRINO, A. Índices morfogênicos e de crescimento durante o estabelecimento e a rebrotação do Capim- Mombaça (PanicummaximumJacq.). Revista Brasileira de Zootecnia, Viçosa, MG, v. 32, n. 4, p. 795-803, 2003. DOI: $10.1590 / \mathrm{S} 1516-35982003000400003$

IWAMOTO, B. S.; CECATO, U.; RIBEIRO, O. L.; MARI, G. C.; PELUSO, E. P.; LOURENÇO, D. A. L. Características morfogênicas do capim-Tanzania fertilizado ou não com nitrogênio nas estações do ano. Bioscience Journal, Uberlândia, v. 31, n. 1, p. 181-193, 2015. DOI: 10.14393/BJ-v31n1a2015-18077

LEMAIRE, G. The physiology of grass growth under grazing: tissue turnover. In: SIMPÓSIO INTERNACIONAL SOBRE PRODUÇÃO ANIMAL EM PASTEJO, 1997, Viçosa, MG. Anais... Viçosa, MG: Universidade Federal de Viçosa, 1997. p. 15-96.

LEMAIRE, G.; CHAPMAN, D. Tissue flows in grazed plant communities. In: HODGSON, J.; ILLIUS, A. $\mathrm{W}$. The ecology and management of grazing systems. Guilford: CAB International, 1996. p. 3-36.

LEMAIRE, G.; HODGSON, J.; CHABBI, A. Grassland productivity and ecosystem services. Cabi: Wallingford, 2011. 287 p.

MARTUSCELlO, J. A.; SILVA L. P.; CUNHA, D. N. F. V.; BATISTA, A. C. S.; BRAZ, T. G. S.; FERREIRA, P. $\mathrm{S}$. Nitrogen fertilization in Massai grass: production and morphogenesis. Ciência Animal Brasileira, Goiânia, v. 6, n. 1, p. 1-13, 2015. DOI: 10.1590/1089-68916i118730 
MERTENS, D. R. Analysis of fiber in feeds its uses feeds evaluation and ration formulation. In: SIMPÓSIO INTERNACIONAL DE RUMINANTES, 1992, Lavras, MG. Anais... Lavras: Sociedade Brasileira de Zootecnia, 1992. p.1-32.

NABINGER, C.; CARVALHO, P. F. C. Ecofisiología de sistemas pastoriles: aplicaciones para su sustentabilidad. Agrociencia, Montevidéu, v. 3, n. 3, p. 18-27, 2009.

NUSSIO, L. G.; MANZANO, R. P.; PEDREIRA, C. G. S. Valor alimentício em plantas do gênero Cynodon. In: SIMPÓSIO SOBRE MANEJO DE PASTAGEM. MANEJO DE PASTAGENS DE TÍFTON, COASTCROSS E ESTRELA, 1998, Piracicaba. Anais... Piracicaba: FEALQ, 1998. P. 203-242.

PINTO, J. C.; GOMIDE, J. A.; MAESTRI, M. Produção de matéria seca e relação folha/ caule de gramíneas forrageiras tropicais, cultivadas em vasos, com duas doses de nitrogênio. Revista Brasileira de Zootecnia, Viçosa, MG, v. 23, n. 3, p. 313-326, 1994.

POMPEU, R. C. F. F.; CÂNDIDO, M. J. D.; LOPES, M. N.; GOMES, F. H. T.; LACERDA, C. F. de; AQUINO, B. F.; MAGALHÃES, J. A. Características morfofisiológicas do capim-aruana sob diferentes doses de nitrogênio. Revista Brasileira de Saúde e Produção Animal, Salvador, v. 11, n. 4, p. 1187-1210, 2010.

RIBEIRO, L.P. Os Latossolos Amarelos do Recôncavo Baiano: Gênese, evolução e degradação. Salvador: Seplantec, CADCT, 1998. 99 p
ROMA, C. F. C.; CECATO, U.; SOARES FILHO, C. V.; SANTOS, G. T.; RIBEIRO, O. L.; IWAMOTO, B. S. Morphogenetic and tillering dynamics in Tanzania grass fertilized and non fertilized with nitrogen according to season. Revista Brasileira de Zootecnia, Viçosa, MG, v. 41, n. 3, p. 565-573, 2012. DOI: 10.1590/S151635982012000300013

SBRISSIA, A. F.; SILVA, S. C. da. O ecossistema de pastagens e a produção animal. A produção animal na visão dos brasileiros. In: REUNIÃO ANUAL DA SOCIEDADE BRASILEIRA DE ZOOTECNIA, 38., 2001, Piracicaba: FEALQ. Anais...Piracicaba: SBZ, 2001. p. 731-754.

SCHNYDER, H.; SCHAUFELE, R.; VISSER, R.; NELSON, J. An integrated view of $\mathrm{C}$ and $\mathrm{N}$ uses in leaf growth zones of defoliated grasses. In: LEMAIRE, G.; HODGSON, J.; MORAES, A.; CARVALHO, P. C. F.; NAGIBER, C. (Ed.). Grassland ecophysiology and grazing ecology. Wallingford: CAB International, 2000. p. 41-60.

SILVA, S. C; NASCIMENTO JÚNIOR, D. Avanços na pesquisa com plantas forrageiras tropicais em pastagens: características morfofisiológicas e manejo do pastejo. Revista Brasileira de Zootecnia, Viçosa, MG, v. 36, n. 4, p. 121-138, 2007. DOI: 10.1590/S151635982007001000014

VALENTINE, I.; MATTWEW, C. Plant growth, development and yield. In: WHITE, J.; HODGSON, J. (Ed.). New Zealand pasture and crop science. Oxford: Oxford University Press, 1999. p. 11-28.

VAN SOEST, P. J. Nutritional ecology of the ruminant. $2^{\text {th }}$ ed. Cornell University Press, Ithaca, 1994. 476 p. 
